\title{
Care transition strategies in Latin American countries: an integrative review
}

\author{
Estratégias de transição de cuidados nos países latino-americanos: uma revisão integrativa \\ Estrategias de transición de cuidados en los países latinoamericanos: una revisión integrativa
}

\author{
Maria Alice Dias da Silva Lima \\ Ana Maria Müller de Magalhães ${ }^{a}$ \\ Nelly Donszelmann Oelke ${ }^{b}$ \\ Giselda Quintana Marques ${ }^{c}$ \\ Elisiane Lorenzini ${ }^{d}$ \\ Luciana Andressa Feil Weber ${ }^{\mathrm{a}}$ \\ Iris Fan ${ }^{b}$
}

\section{How to cite this article:}

Lima MADS, Magalhães AMM, Oelke

ND, Marques GQ, Lorenzini E, Weber LAF, et al. Care transition strategies in Latin American countries: an integrative review. Rev Gaúcha Enferm. 2018;39:e20180119. doi: https://doi.org/10.1590/19831447.2018.20180119. a Universidade Federal do Rio Grande do Sul (UFRGS), Escola de Enfermagem, Programa de Pós-Graduação em Enfermagem. Porto Alegre, Rio Grande do Sul, Brasil.

${ }^{b}$ University of British Columbia (UBC), Okanagan Campus, School of Nursing. Kelowna, Canada.

Secretaria Municipal de Saúde de Porto Alegre. Porto Alegre, Rio Grande do Sul, Brasil.

Universidade Federal do Rio Grande do Sul (UFRGS), Escola de Enfermagem, Núcleo de Estudos sobre Gestão em Enfermagem (NEGE), Porto Alegre, Rio Grande do Sul, Brasil.

\section{ABSTRACT}

Objective: To identify and analyze available literature on care transition strategies in Latin American countries.

Methods: Integrative literature review that included studies indexed in PubMed, LLLACS, Web of Science Core Collection, CINAHL, SCOPUS databases, and the Scientific Electronic Library Online (SciELO), published in Portuguese, Spanish or English, between 2010 and 2017.

Results: Eleven articles were selected and the strategies were grouped into components of care transition: discharge planning, advanced care planning, patient education and promotion of self-management, medication safety, complete communication of information, and outpatient follow-up. These strategies were carried out by multidisciplinary team members, in which nurses play a leading role in promoting safe care transitions.

Conclusions: Care transition activities are generally initiated very close to patient discharge, this differs from recommendations of care transition programs and models, which suggest implementing care transition strategies from the time of admission until discharge.

Keywords: Continuity of patient care. Patient transfer. Health education. Discharge planning. Patient readmission.

\section{RESUMO}

Objetivo: Identificar a literatura disponível sobre estratégias de transição do cuidado entre níveis de atenção à saúde em países da América Latina.

Métodos: Revisão integrativa da literatura que incluiu estudos indexados nas bases de dados PubMed, LLACS, Web of Science Core Collection, CINAHL, SCOPUS e Scientific Electronic Library Online (SciELO), publicados em português, espanhol ou inglês, entre 2010 e 2017. Resultados: Onze artigos foram selecionados e as estratégias foram agrupadas em componentes da transiç̧ão do cuidado: planejamento de alta, planejamento antecipado de cuidados, educação do paciente e promoção do autogerenciamento, segurança da medicação, comunicação completa das informaç̃ões e acompanhamento ambulatorial. Essas estratégias foram realizadas por membros da equipe multidisciplinar, nas quais enfermeiros desempenham um papel de liderança na promoção de transiç̧ões de cuidados seguras. Conclusões: As atividades de transição do cuidado geralmente são iniciadas muito próximas da alta do paciente, isso difere das recomendações de programas e modelos de transição de cuidados, que sugerem a implementação de estratégias transição de cuidado desde o momento da admissão até a alta.

Palavras-chave: Continuidade da assistência ao paciente. Transferência de pacientes.Educação em saúde. Alta do paciente. Readmissão do paciente.

\section{RESUMEN}

Objetivo: Identificar la literatura disponible sobre estrategias de transición del cuidado entre niveles de atención a la salud en países de América Latina.

Métodos: Revisión integradora que incluyó estudios indexadas en las bases de datos PubMed, LLLACS, Web of Science Core Collection, CINAHL, Scopus y Scientific Electronic Library Online (SciELO), publicado en portugués, español o inglés, entre 2010 y 2017.

Resultados: Se seleccionaron once artículos y las estrategias fueron agrupadas en componentes de la transición del cuidado: planificación de alta, planificación anticipada de cuidados, educación del paciente y promoción de la autogestión, seguridad de la medicación, comunicación completa de las informaciones y acompañamiento ambulatorial. Estas estrategias fueron realizadas por miembros del equipo multidisciplinario, en los que las enfermeras desempeñan un papel de liderazgo en la promoción de transiciones de cuidados seguras. Conclusión: Las actividades de transición del cuidado generalmente se inician muy cerca del alta del paciente, esto difiere de las recomendaciones de programas y modelos de transición de cuidados, que sugieren la implementación de estrategias de transición del cuidado desde el momento de la admisión hasta la alta.

Palabras clave: Continuidad de la atención al paciente. Transferencia de pacientes. Educación en salud. Alta del paciente. Readmissión del paciente. 


\section{口INTRODUCTION}

Health services and systems integration is challenging when the desired outcomes are improved healthcare quality and effective use of resources. Integrated health services are managed and delivered to ensure people receive a continuum of health promotion, disease prevention, diagnosis, treatment, disease management, rehabilitation and palliative care services, at the different levels and settings of care $^{(1)}$. Although there is no single model to support health systems integration, ten universal principles were identified, which include a focus on coordinated and cooperative services at all levels of the care continuum, ranging from primary to tertiary care ${ }^{(2)}$. With respect to users, focus on patients and comprehensiveness of health services are considered priorities for tailoring care to the needs of the population ${ }^{(3)}$.

Care transition is one of the domains related to the principles of health systems integration ${ }^{(4)}$. It is defined as a set of planned actions to ensure safe coordination and continuity of care when patients experience a change in health status, or need to be transferred between different locations within the same service or between different healthcare levels $s^{(5)}$. Care transition is a strategy that has an impact on reducing the length of hospital stays and lowering readmissions due to complications ${ }^{(6)}$. This strategy helps reduce costs in health services(7) and enhances the quality of life for patients and their families, especially within a context of constant technological and therapeutic advances, and in terms of patient treatment and the longevity of people with multiple comorbidities ${ }^{(8)}$.

Hospital managers and care providers constantly need to implement care transition strategies to prevent adverse events, emergency department return visits and hospital readmissions within 30 days of discharge. However, there is little information available on effective care transitions for patients and their families. This continues to be an approach that is not commonly used, particularly in relation to hospital-home discharge planning, with fragmentation in post-discharge care ${ }^{(6)}$. Coordination of care transitions is especially important for patients with diverse health needs and multiple comorbidities, who are often dependent on technologies and devices for continuity of care in their homes or other care settings, and require trained professionals and support resources at the time of discharge.

In the international literature, models and programs exist for providing guidance and improving care practices, to achieve safer transitions. Among the professionals from multidisciplinary teams, nurses play a leading role in care transition. Discharge planning, which takes into account possible limitations of patients, communication with primary care professionals, education and instructions for home medication use, follow-up through home visits or by phone, and the use of virtual nurses via internet communication are some of the activities that have yielded positive results for safe transitions ${ }^{(9-10)}$.

There has been an increase in the international literature on care transitions carried out by nurses from hospital to home in the last 5 years, mainly in countries from North America, China, and Europe. Although the growing importance of this issue, there is a lack of research in this area in Brazil and Latin America ${ }^{(11)}$. Therefore, the objective of this study is to to identify and analyze available literature on care transition strategies in Latin American countries.

\section{口 METHODS}

Integrative literature review methodology enables to synthesize results from previous studies on a specific topic. The review was structured according to the following stages: problem identification, literature search, data evaluation, data analysis and synthesis of data extracted from the studies ${ }^{(12)}$. The guiding question was: what is the available literature on care transition strategies in Latin American countries?

The studies were selected by electronic search in the following databases: Medical Literature Analysis and Retrieval System Online (PubMed/MEDLINE), Latin American and Caribbean Center in Health Sciences Information (LILACS), Web of Science Core Collection, Cumulative Index to Nursing and Allied Health Literature (CINAHL), SCOPUS, and Scientific Electronic Library Online (SciELO).

The descriptors used in the search strategy were extracted from the Health Sciences Descriptors (DeCS) and Medical Subject Headings (MeSH), using the following combinations: 1) ("discharge planning" OR "patient discharge" OR "patient transfer" OR "care transition" OR "transition of care" OR "transitional care") AND "medication reconciliation"; 2) "patient education" AND "continuity of care"; 3) ("continuity of care" OR "care transition" OR "transition of care" OR "transitional care") AND "patient education"; 4) ("continuity of care" OR "care transition" OR "transition of care" OR "transitional care") AND ("readmission" OR "patient readmission" OR "hospital readmission"); 5) ("patient education" AND communication) AND ("continuity of care" OR "care transition" OR "transition of care" OR "transitional care"); 6) "patient education" AND communication AND "patient care team".

The inclusion criteria established were full-text articles on the selected databases, published from January 2010 to December 2017, in Portuguese, English, and Spanish, and 
providing information on strategies related to care transitions between different healthcare levels in Latin American countries. Exclusion criteria were: theoretical articles; editorials; integrative, narrative and systematic reviews; and experience reports.

The data collection took place between January and April 2017 and it was updated in March 2018. A total of 1,835 articles were identified. For selection of the studies, the titles and abstracts were read and analyzed. In the case of uncertainty, the research team discussed and decided the inclusion or exclusion of the article. After removal of the duplicates, the titles and abstracts of 1,321 publications were read, of which 14 were assessed for eligibility. Upon reading the full text articles, three additional were removed as they did not meet inclusion criteria. The flowchart shown in Figure 1 illustrates the process of identification, selection and inclusion of the primary studies.
To extract the data from the articles included in the sample, we created and used an instrument that contained information about authors, title, journal, year of publication, objective, method, identification of transition of care components, conclusions, limitations of the study, and recommendations.

We used the Joanna Briggs Institute Levels of Evidence for Effectiveness to classify the articles: Level 1 - Experimental Designs; Level 2 - Quasi-experimental Designs; Level 3 - Observational-Analytic Designs; Level 4 - Observational-Descriptive Studies; Level 5 - Expert Opinion and Bench Research ${ }^{(13)}$.

For the data analysis, the care transition strategies were grouped according to similarity and then summarized based on the key components proposed for ideal care transitions ${ }^{(14)}$ : discharge planning (DP); advance care planning (ACP); patient education and promotion of self-management (PEPS); medication safety (MS); complete communication of information (CCl); outpatient follow-up (OF).
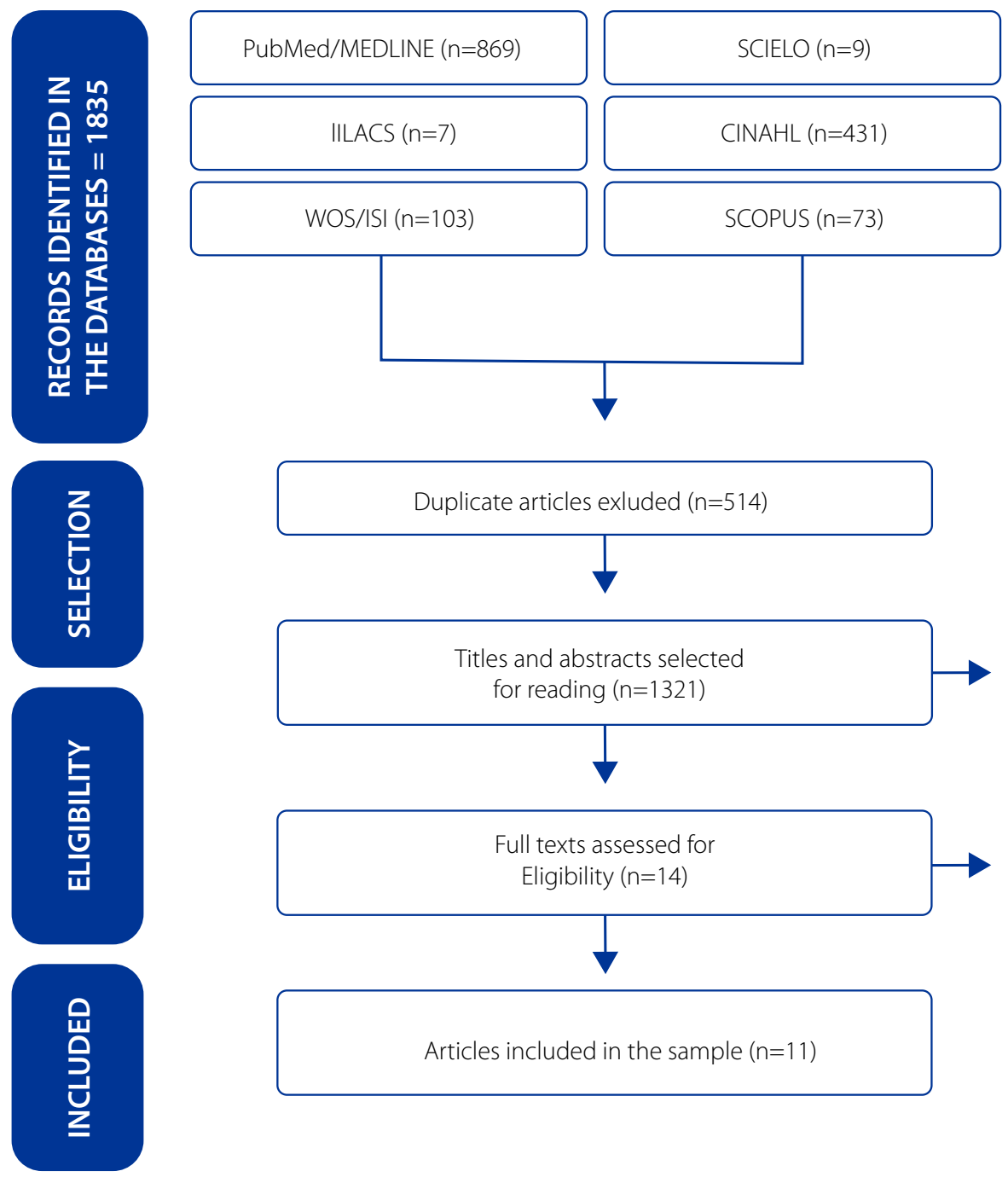

Titles and abstracts exluded $(n=1321)$

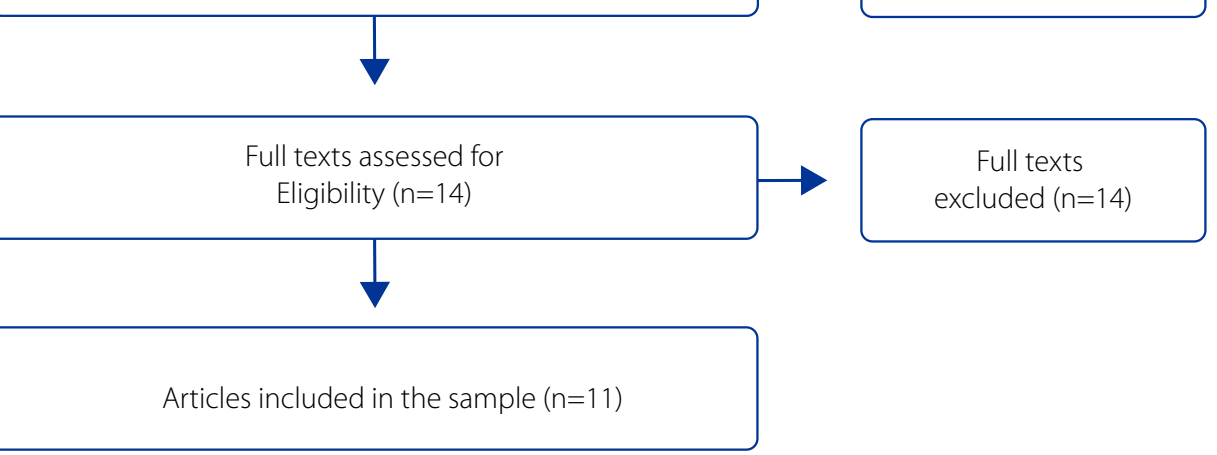

Figure 1 - Flowchart of the data collection and selection of the studies that comprised the sample. Source: Research data, 2018. 


\section{RESULTS}

The final sample was comprised of 11 publications that described strategies for patient care transition between different healthcare levels in Latin American countries. Chart 1 shows the articles that composed the sample analyzed in this study. There were two articles published in 2017, three in 2016, four in 2015, and two in 2014. Three articles were in Portuguese, four in Portuguese and English, four in English, and one in Spanish. The studies were conducted predominantly in the Brazilian (eight), Colombian (two) and Mexican (one) contexts. As for the levels of evidence of the publications, there were two articles with level 1, one article with level 2, one article with level 3 , and seven studies with level 4 .

\begin{tabular}{|c|c|c|c|c|}
\hline $\begin{array}{c}\text { Authors and } \\
\text { Year of } \\
\text { Publication }\end{array}$ & $\begin{array}{l}\text { Country, Lan- } \\
\text { guage, Level } \\
\text { of Evidence }\end{array}$ & Objective & $\begin{array}{c}\text { Method, Setting and } \\
\text { Sample }\end{array}$ & Care Transition Strategies \\
\hline $\begin{array}{l}\text { Góes FGB, } \\
\text { Cabral IE, } \\
2017^{(15)}\end{array}$ & $\begin{array}{l}\text { Brazil } \\
\text { Portuguese } \\
\text { English } \\
\text { Level } 4\end{array}$ & $\begin{array}{l}\text { Analyze and understand } \\
\text { the discourse of } \\
\text { healthcare professionals } \\
\text { and families on the } \\
\text { hospital discharge } \\
\text { process for children } \\
\text { with special healthcare } \\
\text { needs. }\end{array}$ & $\begin{array}{l}\text { Qualitative Research } \\
\text { A Public Pediatric } \\
\text { Teaching hospital in Rio } \\
\text { de Janeiro } \\
10 \text { children with special } \\
\text { healthcare needs, } 6 \\
\text { professionals, and } 11 \\
\text { family members }\end{array}$ & $\begin{array}{l}\text { Health education for } \\
\text { patients/families based on } \\
\text { individual needs (PEPS); } \\
\text { engage family members } \\
\text { in the care of patient/child } \\
\text { during hospitalization (PEPS); } \\
\text { use of feedback method to } \\
\text { review understanding of the } \\
\text { instructions given (PEPS). }\end{array}$ \\
\hline $\begin{array}{l}\text { Ferreira EB et } \\
\text { al., 2017 (16) }\end{array}$ & $\begin{array}{l}\text { Brazil } \\
\text { Portuguese } \\
\text { English } \\
\text { Level } 4\end{array}$ & $\begin{array}{l}\text { To monitor the adverse } \\
\text { effects of antineoplastic } \\
\text { chemotherapy in } \\
\text { patients undergoing } \\
\text { outpatient treatment } \\
\text { through telephone } \\
\text { follow-up as a strategy } \\
\text { to provide comfort. }\end{array}$ & $\begin{array}{l}\text { Longitudinal, } \\
\text { prospective, } \\
\text { quantitative- qualitative } \\
\text { study } \\
\text { High Complexity in } \\
\text { Oncology Center } \\
\text { (CACON) } \\
\text { A total of } 21 \text { patients, } \\
\text { aged between } 30 \text { and } \\
78 \text { years }\end{array}$ & $\begin{array}{l}\text { Telephone follow-up during } \\
\text { the course of treatment } \\
\text { increases the relationship } \\
\text { of trust and creates } \\
\text { opportunities for patients to } \\
\text { clarify questions/doubts (OF); } \\
\text { nursing consultations were } \\
\text { conducted via telephone } \\
\text { during chemo to monitor } \\
\text { patients'signs and symptoms } \\
\text { related to the adverse effects } \\
\text { of chemo (OF) and (PEPS). }\end{array}$ \\
\hline $\begin{array}{l}\text { Figueiredo TP } \\
\text { et al., 2016 }\end{array}$ & $\begin{array}{l}\text { Brazil } \\
\text { Portuguese } \\
\text { Level } 3\end{array}$ & $\begin{array}{l}\text { Analyze the instructions } \\
\text { given at discharge, } \\
\text { described in the } \\
\text { pharmacotherapeutic } \\
\text { referrals and the profile } \\
\text { of patients in post- } \\
\text { discharge contacts. }\end{array}$ & $\begin{array}{l}\text { Retrospective cohort } \\
\text { study } \\
\text { General Public Hospital, } \\
\text { Belo Horizonte, Brazil } \\
135 \text { patients before } \\
\text { hospital discharge } \\
\text { and } 65 \text { patients post- } \\
\text { discharge follow-up }\end{array}$ & $\begin{array}{l}\text { Outpatient monitoring in } \\
\text { the primary care unit(OF); } \\
\text { care planning at the time of } \\
\text { discharge (DP); telephone } \\
\text { calls for follow-up (OF); patien } \\
\text { education and promotion of } \\
\text { medication self-management } \\
\text { (PEPS) and (MS); } \\
\text { sending patients' information } \\
\text { to the health care team at the } \\
\text { primary care unit (CCI). }\end{array}$ \\
\hline
\end{tabular}




\begin{tabular}{|c|c|c|c|c|}
\hline $\begin{array}{l}\text { Lima LF et al., } \\
2016^{(18)}\end{array}$ & $\begin{array}{l}\text { Brazil } \\
\text { Portuguese } \\
\text { English } \\
\text { Level } 4\end{array}$ & $\begin{array}{l}\text { Describe and analyze } \\
\text { pharmaceutical } \\
\text { instructions provided at } \\
\text { the time of discharge of } \\
\text { transplant patients. }\end{array}$ & $\begin{array}{l}\text { Cross-sectional, } \\
\text { descriptive and } \\
\text { retrospective study } \\
\text { University Hospital } \\
\text { of Walter Cantídio, } \\
\text { Fortaleza, Brazil } \\
74 \text { patients }\end{array}$ & $\begin{array}{l}\text { Discharge planning (DP) } \\
\text { and health education with } \\
\text { a focus on self-care and diet } \\
\text { by multiprofessional teams } \\
\text { (PEPS); educational actions } \\
\text { aimed at medication safety } \\
\text { (MS); provide patients with a } \\
\text { pharmaceutical orientation } \\
\text { prior to discharge at the } \\
\text { clinical ward (PEPS), and } \\
\text { follow-up at the outpatient } \\
\text { clinic (OF) }\end{array}$ \\
\hline $\begin{array}{l}\text { Oliveira PR et } \\
\text { al., 2016 }\end{array}$ & $\begin{array}{l}\text { Brazil } \\
\text { English } \\
\text { Level } 4\end{array}$ & $\begin{array}{l}\text { Describe the } \\
\text { implementation } \\
\text { process and preliminary } \\
\text { results of an outpatient } \\
\text { parenteral antimicrobial } \\
\text { therapy program (OPAT) } \\
\text { for treating orthopedic } \\
\text { infections in a public } \\
\text { health service centre in } \\
\text { São Paulo, Brazil. }\end{array}$ & $\begin{array}{l}\text { Descriptive study } \\
\text { Orthopedic and } \\
\text { Traumatology Institute } \\
\text { of São Paulo University } \\
\text { Hospital, São Paulo, } \\
\text { Brazil } \\
450 \text { primary healthcare } \\
\text { professionals, } 116 \\
\text { patients were discharge } \\
\text { for OPAT. }\end{array}$ & $\begin{array}{l}\text { Outpatient monitoring in } \\
\text { primary care units (OF); } \\
\text { health education activities } \\
\text { with a focus on central } \\
\text { venous catheters (PEPS); } \\
\text { discharge planning based } \\
\text { on assessment of health } \\
\text { conditions, cognitive capacity, } \\
\text { and social support for getting } \\
\text { to treatment units (DP); a } \\
\text { clinical pathway including } \\
\text { detailed treatment plans was } \\
\text { utilized as a communication } \\
\text { tool between hospitals and } \\
\text { primary care facilities (CCI). }\end{array}$ \\
\hline $\begin{array}{l}\text { Hernandez } \\
\text { AMT, 2015(20) }\end{array}$ & $\begin{array}{l}\text { Mexico } \\
\text { Spanish } \\
\text { Level } 4\end{array}$ & $\begin{array}{l}\text { Formulate a } \\
\text { comprehensive, } \\
\text { specialized, } \\
\text { individualized care } \\
\text { plan during discharge } \\
\text { and home follow- } \\
\text { up for a preschooler } \\
\text { with functional and } \\
\text { morphological heart } \\
\text { changes, based on the } \\
\text { Virginia Henderson care } \\
\text { model. }\end{array}$ & $\begin{array}{l}\text { Case study } \\
\text { National Institute of } \\
\text { Cardiology lgnacio } \\
\text { Chávez, Mexico } \\
1 \text { pediatric patient and } \\
\text { his family }\end{array}$ & $\begin{array}{l}\text { Monitoring through home } \\
\text { visits (OF); medication safety } \\
\text { instructions (MS); patient and } \\
\text { caregiver education (PEPS). }\end{array}$ \\
\hline $\begin{array}{l}\text { Carmo TM et } \\
\text { al., 2015 (21) }\end{array}$ & $\begin{array}{l}\text { Brazil } \\
\text { English } \\
\text { Level } 1\end{array}$ & $\begin{array}{l}\text { Evaluate the feasibility } \\
\text { of psychological } \\
\text { interventions and } \\
\text { palliative care for } \\
\text { patients with advanced } \\
\text { cancer. }\end{array}$ & $\begin{array}{l}\text { Randomized, open- } \\
\text { label, phase II trial, with } \\
2 \text { intervention arms and } \\
\text { a control group } \\
\text { Oncology clinics } \\
\text { at Barretos Cancer } \\
\text { Hospital, São Paulo, } \\
\text { Brazil } \\
150 \text { Patients }\end{array}$ & $\begin{array}{l}\text { Advance care planning by } \\
\text { multidisciplinary teams (ACP); } \\
\text { educational and psychological } \\
\text { interventions to provide } \\
\text { support to families and } \\
\text { patients (PEPS). }\end{array}$ \\
\hline
\end{tabular}




\begin{tabular}{|c|c|c|c|c|}
\hline $\begin{array}{l}\text { Aristizábal D et } \\
\text { al., 2015(22) }\end{array}$ & $\begin{array}{l}\text { Colombia } \\
\text { English } \\
\text { Level } 2\end{array}$ & $\begin{array}{l}\text { To evaluate the effect } \\
\text { of a care program } \\
\text { designed according to a } \\
\text { comprehensive } \\
\text { ambulatory care } \\
\text { model (CACM) on the } \\
\text { appearance of new } \\
\text { cardiovascular/coronary } \\
\text { events in patients } \\
\text { with acute coronary } \\
\text { syndrome. }\end{array}$ & $\begin{array}{l}\text { Quasi- experimental } \\
\text { intervention study } \\
\text { Cardiovic Clinic } \\
\text { Medellín, Colombia } \\
442 \text { patients }\end{array}$ & $\begin{array}{l}\text { Telephone and treatment plan } \\
\text { follow-up post-discharge (OF); } \\
\text { patient education (PEPS) and } \\
\text { use of the feedback method } \\
\text { to review understanding of } \\
\text { medication safety (MS). }\end{array}$ \\
\hline $\begin{array}{l}\text { Becerra- } \\
\text { Camargo J et } \\
\text { al., 2015(23) }\end{array}$ & $\begin{array}{l}\text { Colombia } \\
\text { English } \\
\text { Level } 1\end{array}$ & $\begin{array}{l}\text { To measure the impact } \\
\text { of potential adverse } \\
\text { drug events by having } \\
\text { the pharmacist collect } \\
\text { the history of drugs } \\
\text { in use, before the } \\
\text { consultation with } \\
\text { the physician in the } \\
\text { emergency department. }\end{array}$ & $\begin{array}{l}\text { Multicentre, double- } \\
\text { blind, randomised, } \\
\text { controlled parallel- } \\
\text { group study } \\
\text { Three large teaching } \\
\text { hospitals, Bogota, } \\
\text { Colombia } \\
\text { 270 Patients }\end{array}$ & $\begin{array}{l}\text { Medication reconciliation } \\
\text { between pharmacists, } \\
\text { doctors, and patients } \\
\text { (MS); communication } \\
\text { by phone with family } \\
\text { members or caregivers to } \\
\text { confirm patients' current } \\
\text { medication regime is } \\
\text { correct (MS). }\end{array}$ \\
\hline $\begin{array}{l}\text { Marques LFG, } \\
\text { Romano- } \\
\text { Lieber NS, } \\
2014^{(24)}\end{array}$ & $\begin{array}{l}\text { Brazil } \\
\text { Portuguese } \\
\text { English } \\
\text { Level } 4\end{array}$ & $\begin{array}{l}\text { This study aims } \\
\text { to understand } \\
\text { the dynamics and } \\
\text { challenges of care } \\
\text { provided to patients } \\
\text { by hospital providers } \\
\text { focusing on safe use } \\
\text { of medications after } \\
\text { discharge. }\end{array}$ & $\begin{array}{l}\text { Qualitative, } \\
\text { Exploratory Study } \\
\text { São Paulo University } \\
\text { Hospital, São Paulo, } \\
\text { Brazil } \\
11 \text { Healthcare } \\
\text { Professionals (4 } \\
\text { physicians, } 3 \text { nurses, } 3 \\
\text { pharmacists, } 1 \text { social } \\
\text { worker) } \\
\end{array}$ & $\begin{array}{l}\text { Discharge planning only } \\
\text { for patients with complex } \\
\text { health care needs (DP); } \\
\text { home visit follow-ups } \\
\text { for patients under the } \\
\text { Home Care Program (OF); } \\
\text { medication education and } \\
\text { counselling for pediatric } \\
\text { patients and caregivers } \\
\text { (PEPS) and (MS). }\end{array}$ \\
\hline $\begin{array}{l}\text { Costa JM et } \\
\text { al., 2014(25) }\end{array}$ & $\begin{array}{l}\text { Brazil } \\
\text { Portuguese } \\
\text { Level } 4\end{array}$ & $\begin{array}{l}\text { Present the results } \\
\text { of a project to } \\
\text { guide discharged } \\
\text { patients on the use } \\
\text { of antimicrobial } \\
\text { pharmacotherapy, } \\
\text { carried out in a } \\
\text { teaching hospital. }\end{array}$ & $\begin{array}{l}\text { Retrospective, } \\
\text { descriptive, and } \\
\text { exploratory study } \\
\text { Hospital Risoleta } \\
\text { Tolentino Neves, Belo } \\
\text { Horizonte, Brazil }\end{array}$ & $\begin{array}{l}\text { Telephone follow-ups post } \\
\text { discharge (OF); Discharge } \\
\text { planning (DP); patient } \\
\text { orientation to medication } \\
\text { safety (PEPS) and (MS); }\end{array}$ \\
\hline
\end{tabular}

Chart 1 - Reviewed articles by author, year of publication, country, language, objectives and care transition strategies. Source: Research data, 2018.

The care transition strategies carried out in the Latin American context were summarized according to the proposed grouping and described as follows.

\section{Discharge Planning (DP)}

Five studies were found related to discharge planning $^{(17-19,24-25)}$. Planning was centered on the health conditions of patients ${ }^{(19)}$, cognitive capacity ${ }^{(17,19)}$, social support, and the needs of patients ${ }^{(19)}$. Care plans included drug lists and instructions(18,24-25), social support to access health care services ${ }^{(19)}$, underlying illnesses, warning signs and symptoms, nutritional care, instructions regarding continued use of medications, and clinical follow-ups ${ }^{(18,25)}$. One study developed a discharge planning guide around safe medication usage for pediatric patients and their caregivers due to their complex health needs ${ }^{(24)}$. 


\section{Advance Care Planning (ACP)}

Advance care planning may begin in the hospital or outpatient setting, it is an essential step to ensure goals of care are clearly communicated between patients and healthcare $^{(14)}$. Moreover, misconceptions and stigmatization of palliative care (PC) as "a place to die" are barriers for patients to receive timely referrals to palliative care programs ${ }^{(21)}$. In addition, one study suggested incorporating psychosocial and educational sessions to patients with advanced cancer to adequately prepare them for PC consultations after an early referral to $P C^{(21)}$. It was noted that early $P C$ referrals to patients with advanced cancer was associated with lower levels of depression symptoms compared with standard oncologic treatment ${ }^{(21)}$.

\section{Patient Education and Promotion of Self- management (PEPS)}

Patient education and promotion of self-management activities were identified in ten studies of this review ${ }^{(15-22,24-25)}$. Instructions related to self-care and the treatment prescribed at discharge were provided most of the time by nurses ${ }^{(15-16,20)}$, multi-professional teams ${ }^{(18-19,21-22,24)}$, pharmacists for drug use ${ }^{(17,25)}$. Educational actions were focused on the use of central venous catheters ${ }^{(19)}$, potential adverse effects of drugs ${ }^{(16-17,25)}$, use of medications ${ }^{(17-18,20,22,24-25)}$, selfcare and proper diet ${ }^{(18)}$, individual needs ${ }^{(15,20-21,24)}$ and educational materials ${ }^{(2,22)}$.

Promotion of self-management is a crucial step in the pre and post discharge phases as clinicians can provide counseling on self-care instructions, warning signs and symptoms, and major diagnoses ${ }^{(17)}$. Moreover, this step can engage both the client and the caregivers to ensure discharge teaching is understood. In this review, only one study was identified involving promotion of self-management as one of the strategies of care transition. The study highlighted the importance of involving caregivers and family members in the care of clients during hospitalization $^{(15)}$. As a result of this care transition strategy, caregivers are better able to care for patients post discharge as they are equipped with the knowledge and skills they have learnt during the patients' hospitalization.

\section{Medication Safety (MS)}

Medication safety activities were described in seven studies. The actions carried out by multidisciplinary teams focused primarily on educational activities ${ }^{(17,20)}$, such as the use of personalized files or plans with a detailed de- scription of the drugs in use, and the use of the feedback method to review understanding of medication safety ${ }^{(22)}$, to facilitate understanding and reduce possibilities of post-discharge drug use errors ${ }^{(18,25)}$. The intervention activities of clinical pharmacists, who collected data about drugs in use before medical consultations in emergency departments ${ }^{(23)}$ and performed daily reviews of prescriptions for joint adjustments with physicians ${ }^{(24)}$ were described as activities that promote patient safety in relation to drug use during hospital stays.

\section{Complete Communication of Information (CCI)}

Complete communication of information was achieved through sending patients' information to the healthcare team at the primary care unit via email regarding patients' reason for hospitalization, medication records, prescriptions, treatment, nutritional needs, access to healthcare services, social support, and special considerations ${ }^{(17)}$. In addition, one Brazilian article highlighted the partnership between hospitals and primary care facilities that established a safe and cost-effective program for treating orthopedic infections to prevent antimicrobial resistance ${ }^{(19)}$. Under this program, patients were able to continue their antimicrobial treatment in primary healthcare clinics near their home ${ }^{(19)}$. To ensure the continuity of outpatient treatment, a clinical pathway was created to aid in the communication between healthcare professionals, it included detailed individualized treatment plans and medication regime that clinicians could utilize ${ }^{(19)}$.

\section{Outpatient Follow-up (OF)}

In this review, eight studies were identified that referred to outpatient follow-up, and were carried out in three different settings: home ${ }^{(16,20,22,24-25)}$, outpatient clinic ${ }^{(18)}$, primary health care units ${ }^{(17,19)}$. Home follow-up was done through phone calls $s^{(16-17,22,25)}$ or home visits ${ }^{(20,24)}$. The follow-up was done by nurses ${ }^{(16,20,24)}$, pharmacists ${ }^{(25)}$, multidisciplinary teams ${ }^{(18-19,22)}$. Nurses were identified as the main coordinators in the creation of follow-up plans ${ }^{(20,22)}$ and it was noted that physicians and nurses worked together to monitor treatment and home care ${ }^{(19)}$.

\section{DISCUSSION}

The literature identified major problems with regards to coordinating care between different levels of care due to a variety of factors, such as a lack of standardized processes and communication between healthcare profes- 
sionals, in both the transition from hospital to home and in the transition from primary care to emergency or hospital services ${ }^{(26-27)}$.

The components identified for care transitions indicated that some strategies adopted by health professionals corresponded to interventions and recommendations from programs and care transition models described in the literature ${ }^{(10,14)}$. However, they were occasional initiatives, anchored in research projects or care protocols, which are not yet systematically structured and implemented in health services and systems.

The most cited care transition strategy in the studies was patient education and promotion of self-management, which presupposes participation in and construction of care protocols based on information shared between professionals and patients. During these times, health professionals develop educational or instructional strategies designed to facilitate adherence to treatment by patients or to characterize home care procedures. Adoption of health education strategies is essential for effective care transitions and enables patients to be involved in planning their own care in partnership with health professionals ${ }^{(28)}$; medication reconciliation and adherence to treatment, with possible reductions in readmission rates ${ }^{(29)}$. The use of participatory educational strategies is beneficial to the learning process, since people retain content better when they hear instructions, observe what nurses are doing, can ask questions, and perform their own care ${ }^{(30)}$.

Continuous health education and guidance activities with a focus on promotion can be started long before hospitalization and monitored when patients return home. It is essential to develop individualized education plans ${ }^{(28,31)}$ that respect the way patients think and live, within their social and cultural context. There is also an underlying notion of shared decision-making that endeavors to promote the autonomy of individuals based on their choices, so that health education occurs within the context of partnerships.

Another dimension that was assigned considerable importance in this review was discharge planning. However, discharge care plans are often formulated and delivered at the time of discharge from the hospital, which can lead to a buildup of information, future uncertainties and lack of care safety ${ }^{(32)}$. These difficulties were partially addressed in one study, which showed there was no systematized coordination between professionals and health services in terms of patient discharge preparation ${ }^{(24)}$. Communication failures and work organization modes resulted in health team members only becoming aware of discharges on the day patients were returning home, thereby preventing any care transition actions. Problems in prescriptions also resulted in patients returning to the hospital to receive clarifications ${ }^{(24)}$. In other contexts, programs are described in which the discharge processes are implemented throughout the hospital stay to make the care transition more effective ${ }^{(28,33)}$

Hospitalization provides the opportunity to carry out educational and preparatory strategies for discharge, to increase the capacity for patient self-care and strengthen adherence to treatment. It has been found that the better the discharge planning and preparation of the patient, with pre and post-discharge interventions, the greater the success of transitions, with positive outcomes ${ }^{(32)}$. Initiating guidelines contained in discharge care plans late in the care process hinders adaptation to the new health condition and prolongs rehabilitation, with negative consequences for patients and families ${ }^{(30)}$.

Medication management during care transitions can have a positive impact on the clinical results of patients ${ }^{(34)}$. In a Canadian study ${ }^{(35)}$, there were reports of instructional failures and lack of understanding of patients regarding the purpose and effect of medications in use. Some patients did not remember receiving drug-related explanations, which resulted in unsafe medication usage.

The intervention of pharmaceutical professionals who collected data about medications or reviewed prescriptions in use was reported as being positive in the promotion of patient safety. In this context, it can be noted that clinical pharmaceutical actions, which have been increasing in recent years, are crucial for preventing incidents and promoting continuity in care transitions. A study ${ }^{(34)}$ conducted in the United States showed an 11\% decrease in readmission of patients who had received follow-up from a pharmacist throughout hospitalization and in the preparation for discharge. Given the complexity and financing problems of health systems around the world, investing in strategies to improve coordination and communication between interprofessional teams and users can greatly contribute to reducing incidents and improve care transitions. For example, medication reconciliation and drug treatment maintenance and adherence are essential to patient safety.

Complete communication of information is related to the information that is expected to be included in discharge summaries and other documents of information transfer from hospital to postdischarge care ${ }^{(14)}$. Various strategies for communication of information between health teams, such as email, phone calls and detailed discharge summaries, were identified in the studies. These initiatives were considered positive and can help improve 
care transition processes in health systems. Communication of information on the care provided, among teams and health services, were highlighted as it plays an essential role in maintaining continuity of care, and preventing adverse events in patients ${ }^{(26)}$.

Outpatient follow-up with close monitoring and managing symptoms post-discharge is crucial to maintain continuity of care for patients. If these strategies are carried out effectively, it will allow problems and concerns to be detected and addressed early, which will further prevent unnecessary readmissions and undue risks for patients ${ }^{(14)}$. Outpatient follow-up is essential for effective continuity of care in the home environment. In addition, elderly patients with chronic diseases and multiple comorbidities require continuous care over time. Nurses have identified the importance of this and in various studies are the professionals who do follow-up ${ }^{(36-37)}$, aimed at avoiding unnecessary readmissions.

A study with elderly patients receiving outpatient follow-up identified that continuity of outpatient care was associated with lower rates of avoidable hospitalization ${ }^{(36)}$. However, fragmentation in the care continuity in Brazilian clinical practices have been identified, and few professionals manage to do post-discharge follow-up of patients, due to communication failures between different healthcare levels and ineffective management of health services ${ }^{(38)}$, which denies users comprehensive, quality care.

To avoid post-discharge care discontinuities, strategies to improve follow-up effectiveness are being implemented. Telephone calls and home visits are used most often and have been efficient. Patients who received phone follow-up obtained better drug treatment results and experienced fewer side effects ${ }^{(37)}$. Home follow-up has proven to be effective in care management and empowerment of patients and families ${ }^{(28)}$, enabling the creation of bonds with professionals and greater chances of continued follow-up at the primary health care level. It should be emphasized that the combined use of these two strategies can improve care management and continuity in the community.

Advance care planning is an essential step to ensure goals of care are clearly communicated between patients and healthcare professionals during hospitalization and post-discharge ${ }^{(14)}$. Furthermore, those goals need to be established in accordance with patients' values and preferences. Exercising this strategy effectively will ensure the continuity of care when patients are transferred between or within health care services. This will further prevent unnecessary readmissions to hospitals, or intensive care units, and greatly improve the quality of life for cancer patients by decreasing stress and anxiety associated with readmis- sions ${ }^{(21)}$. Unfortunately, given the relative importance of advance care planning in cancer patients, the prevalence of this strategy for those with advanced cancer is poor in Brazil $^{(21)}$. Thus, implementing advance care plans and increasing awareness on the benefits of palliative care are salient factors that health professionals need to take into consideration when caring for those with cancer. Even though advance care planning has the potential to improve the quality of life for patients with cancer, the effects of complex interventions in this population in Brazil are unknown. Therefore, further research and work in this area are needed to establish formal advance care protocols and guidelines for cancer patients.

To promote safe care transitions, different activities were carried out by healthcare providers from multi-professional teams. The work and leading role of nurses in this process have been mentioned. The actions they performed include: implementation of health promotion educational strategies to increase adherence to treatment; creation of personalized care plans, based on patients' needs; post-discharge follow-up through home visits and phone calls; and training primary care teams on how to care for central venous catheters.

Among the members of multi-professional teams, nurses are qualified agents for carrying out activities related to health promotion and protection, due to the contextualized and broad knowledge of their training, and since they accompany patients throughout most of their hospital stay, especially in institutional venues ${ }^{(30)}$.

All the articles included in this review described activities and some strategies for care transitions, however no measurement of outcomes was completed. Evaluation of the effectiveness of strategies is required to better understand best practices for care transitions.

A limitation of this research was the minimal number of studies found; it is evident that there is a lack of exploration on this topic in the literature. The inclusion criteria for fulltext articles available in the selected databases may have restricted the identification of studies for the review.

Given this emerging topic in the Latin American healthcare practices, the results of this review can provide support and contribute to the ability of experts in the area of integrated health care. The results highlight the importance to promote discussion about this topic in the healthcare research and teaching. Further research on the impact of care transitions on the quality, safety, cost and effectiveness of health care provided within all environments of the care continuum is required to improve outcomes for patients, providers, and health systems. 


\section{口INAL CONSIDERATIONS}

An integrative review was performed in the present study to identify strategies related to care transitions between different healthcare levels in Latin American countries. This method proved to be effective since it was possible to explore, summarize and present transition strategies from studies conducted on the basis of different methodological approaches and settings. The results showed that care transition concepts are under developed in the Latin American literature.

Only two articles used experimental design, with level of evidence 1 , so there is a lack of evidence based practice. For this reason, we were unable to determine the effectiveness of those strategies, if they were to be carried out in different setting. Therefore, more control trials are needed to determine the feasibilities of these strategies.

The care transition strategies identified in the studies encompassed a set of components, such as: discharge planning, advance care planning, patient education and promotion of self-management, medication safety, complete communication of information and outpatient follow-up. These strategies were carried out by multidisciplinary team members, where nurses play a leading role in promoting safe care transitions. These activities were generally initiated very close to patient discharge, diverging therefore from the recommendations of care transition programs in the international literature, which focus on starting actions from the time of admission until discharge.

\section{REFERENCES}

1. World Health Organization (CH). WHO global strategy on people-centred and integrated health services: interim report. Geneva: World Health Organization; 2015 [cited 2018 Apr 08]. Available from: http://www.who.int/iris/handle/10665/155002.

2. Suter E, Oelke ND, Adair CE, Armitage GD. Ten key principles for successful health systems integration. Healthc Q. 2009 [cited 2017 Nov 24];13(Spec No):16-23. Available from: https://www.ncbi.nlm.nih.gov/pmc/articles/PMC3004930/.

3. Lima MADS, Van-Vliet-Brown C, Oelke ND, Witt R, Rostami M, Hepp S. Patient/ user perceptions on the principles of integration [Conference abstract]. Int J Integr Care. 2015;15(8):[approx. 3 p.]. doi: https://doi.org/10.5334/ijic.2347.

4. Suter E, Oelke ND, Lima MADS, Stiphout M, Janke R, Witt RR, et al. Indicators and measurement tools for health systems integration: a knowledge synthesis. Int J Integr Care. 2017;17(6):4,1-17. doi: http://doi.org/10.5334/ijic.3931.

5. Registered Nurses' Association of Ontario. Care transitions. Toronto: RNAO; 2014 [cited 2018 Mar 24]. Clinical best practice guidelines. Available from: https:// rnao.ca/sites/rnao-ca/files/Care_Transitions_BPG.pdf.

6. RennkeS, Nguyen OK, Shoeb MH, MaganY, Wachter RM, Ranij SR. Hospital-initiated transitional care interventions as a patient safety strategy. Ann Intern Med. 2013;158(5 Part 2):433-40. doi: https://doi.org/10.7326/0003-4819-158-5201303051-00011.
7. Fleming MO, Haney TT. Improving patient outcomes with better care transitions: the role for home health. Care transitions and advanced home care models. Cleve Clin J Med. 2013;80(Suppl 1):eS2-S6. Available from: http://www.mdedge.com/sites/defaul/files/issues/articles/Fleming_CareTransitions.pdf.

8. Meisinger C, Stollenwerk B, Kirchberger I, Seidl H, Wende R, Kuch B, et al. Effects of a nurse-based case management compared to usual care among aged patients with myocardial infarction: results from the randomized controlled KORINNA study. BMC Geriatr. 2013;13:115. doi: https://doi.org/10.1186/14712318-13-115.

9. Hirschman KB, Shaid E, McCauley K, Pauly MV, Naylor MD. Continuity of care: the Transitional Care Model. Online J Issues Nurs. 2015 [cited 2018 Mar 24];20(3):1. Available from: http://ojin.nursingworld.org/MainMenuCategories/ANAMarketplace/ANAPeriodicals/OJN/TableofContents/Nol-20-2015/No3-Sept-2015/ Continuity-of-Care-Transitional-Care-Model.html.

10. Enderlin CA, McLeksley N, Rooker IL, Steinhauser C, D'Avolio D, Gusewelle R, et al. Review of current conceptual models and frameworks to guide transition of care in older adults. Geriatric Nurs. 2013;34(1):47-52. doi: https://doi. org/10.1016/j.gerinurse.2012.08.003.

11. Weber LAF, Lima MADS, Acosta AM, Marques GQ. Care transition from hospital to home: integrative review. Cogitare Enferm. 2017;(22)3:47615. doi: https:// doi.org/10.5380/ce.v22i3.47615.

12. Whittemore R, Knaf K. The integrative review: updated methodology.J Adv Nurs. 2005;52(5):546-53. doi: https://doi.org/10.1111/j.1365-2648.2005.03621.X.

13. Joanna Briggs Institute (AU) [Internet]. Adelaide: JBl; c2018 [cited 2018 Mar 24]. Levels of evidence 2014; [about 6 screens]. Available from: http://joannabriggs.org/jbi-approach.htm|\#tabbed-nav=Levels-of-Evidence.

14. Burke RE, Kripalani S, Vasilevskis EE, Schnipper JL. Moving beyond readmission penalties: creating an ideal process to improve transitional care. J Hosp Med. 2013;8(2):102-9. doi: https://doi.org/10.1002/jhm.1990.

15. Góes FGB, Cabral IE. Discourses on discharge care for children with special healthcare needs. Rev Bras Enferm. 2017;70(1):154-61. doi: https://doi. org/10.1590/0034-7167-2016-0248.

16. Ferreira EB, Cruz FOAM, Jesus CAC, Pinho DLM, Kamada I, Reis PED. Telephone contact as a strategy for the promotion of comfort to the patient submitted to chemotherapy. J Nurs UFPE on line. 2017[cited 2018 Mar 12];11(5):1936-42. Available from: https://periodicos.ufpe.br/revistas/revistaenfermagem/article/ view/23343/18949.

17. Figueiredo TP, Carmo Jr NM, Groia RCS, Pereira RCC, Silveira RR, Malta IS, et al. Análise das intervenções realizadas na alta hospitalar de idosos acompanhados em serviço de orientação e referenciamento farmacoterapêutico. Rev APS. 2016 [cited 2017 Nov 15];19(3):376-83. Available from: https://aps.uff.emnuvens. com.br/aps/article/view/2722/1014.

18. Lima LF, Martins BC, Oliveira FR, Cavalcante RM, Magalhães VP, Firmino PY, etal. Pharmaceutical orientation at hospital discharge of transplant patients: strategy for patient safety. Einstein. 2016;14(3):359-65. doi: https://doi.org/10.1590/ S1679-45082016A03481.

19. Oliveira PR, Felix CS, Carvalho VC, Giovani AM, Reis RS, Beraldo M, et al. Outpatient parenteral antimicrobial therapy for orthopedic infections: a successful public healthcare experience in Brazil. Braz J Infect Dis. 2016;20(3):272-5. doi: https://doi.org/10.1016/j.bjid.2016.03.005.

20. Hernández Tapia AM. Plan de alta y seguimiento domiciliario a un preescolar con alteraciones funcionales y morfológicas del corazón. Rev Mex Enferm Cardiol. 2015 [cited 2017 Nov 13];23(1):22-7. Available from: http://www.medigraphic.com/pdfs/enfe/en-2015/en151d.pdf. 
21. Carmo TM, Paiva BSR, Siqueira MR, Rosa LTB, Oliveira CZ, Nascimento MAS, et al. A phase II study in advanced cancer patients to evaluate the early transition to palliative care (the PREPArE trial): protocol study for a randomized controlled trial. Trials. 2015;16:160. doi: https://doi.org/10.1186/s13063-015-0655-8.

22. Aristizábal D, Gallo J, Valencia A, Jaime J, Correa M, Aristizábal A, et al. Effect of a comprehensive ambulatory care model on outcomes of patients with acute coronary syndrome in Colombia. Rev Panam Salud Publica. 2015 [cited 2017 Nov 15];38(5):362-9. Available from: https://www.scielosp.org/article/rpsp/2015. v38n5/362-369/en/.

23. Becerra-Camargo J, Martínez-Martínez F, García-Jiménez E. The effect on potential adverse drug events of a pharmacist-acquired medication history in an emergency department: a multicentre, double-blind, randomised, controlled, parallel-group study. BMC Health Serv Res. 2015;13:337. doi: https://doi. org/10.1186/s12913-015-0990-1.

24. Marques LFG, Romano-Lieber NS. Patient safety and medication use after discharge: exploratory study. Saúde Sociedade. 2014;23(4):1431-44. doi: https:// doi.org/10.1590/S0104-12902014000400025.

25. Costa JM, Abelha LL, Pinto IVL, Reis AMM. Análise de um programa para otimização da transição do cuidado de pacientes em terapia antimicrobiana. Rev APS. 2014 [cited 2017 Nov 15];17(3):318-24. Available from: https://aps. uff.emnuvens.com.br/aps/article/view/2114/823.

26. Okafor N, Mazzillo J, Miller S, Chambers KA, Yusuf S, Garza-Miranda V, et al. Improved accuracy and quality of information during emergency department care transitions. West J Emerg Med. 2017;18(3):459-65. doi: https://doi. org/10.5811/westjem.2016.12.30858.

27. Luu NP, Pitts S, Petty B, Sawyer MD, Dennison-Himmelfarb C, Boonyasai RT, et al. Provider-to-provider communication during transitions of care from outpatient to acute care: a systematic review. J Gen Intern Med. 2015;31(4):417-25. doi: https://doi.org/10.1007/s11606-015-3547-4.

28. Ulin K, Olsson LE, Wolf A, Ekman I. Person-centred care: an approach that improves the discharge process. Eur J Cardiovasc Nurs. 2015;15(3)e19-26. doi: https://doi.org/10.1177/1474515115569945.

29. Gunadi S, Upfield S, Pham ND, Yea J, Schmiedeberg MB, Stahmer GD. Development of a collaborative transitions-of-care program for heartfailure patients. Am J HealthSyst Pharm. 2015;72(13):1147-52. doi: https://doi.org/10.2146/ajhp140563.
30. Gomes B, Martins SS. A pessoa estomizada: análise das práticas educativas de enfermagem. ESTIMA. 2016;14(3):146-53. doi: https://doi.org/10.5327/ Z1806-3144201600030007.

31. Rosado SR, Cicarini WB, Filipini CB, Lima RS, Dázio LMR. Práticas educativas realizadas pelo enfermeiro à pessoa com estomia. Enferm Bras. 2015 [cited 2017 Nov 22];14(4):235-41. Available from: http://portalatlanticaeditora.com.br/ index.php/enfermagembrasil/article/viewFile/47/53.

32. Puls SE, Guerrero KS, Andrew DA. Facilitating safe patient transition of care: a qualitative systematic review. J Nurs Educ Pract. 2014;4(6):37-52. doi: https:// doi.org/10.5430/jnep.v4n6p37.

33. Zhu QM, Liu J, Hu HY, Wang S. Effectiveness of nurse-led early discharge planning programmes for hospital inpatients with chronic disease or rehabilitation needs: a systematic review and meta-analysis. J Clin Nurs. 2015;24(1920):2993-3005. doi: https://doi.org/10.1111/jocn. 12895

34. Rafferty A, Denslow S, Michalets EL. Pharmacist-provided medication management in interdisciplinary transitions in a community hospital (PMIT). Ann Pharmacotherap. 2016;50(8):649-55. doi: https://doi. org/10.1177/1060028016653139.

35. Lang A, Macdonald M, Marck P, Toon L, Griffin M, Easty T, et al. Seniors managing multiple medications: using mixed methods to view the home care safety lens. BMC Health Serv Res. 2015;15:548. doi: https://doi.org/10.1186/s12913-0151193-5.

36. Nyweide DJ, Anthony DL, Bynum JPW, Strawderman RL, Weeks WB, Casalino $L P$, et al. Continuity of care and the risk of preventable hospitalization in older adults. JAMA Intern Med. 2013;173(20):1879-85. doi: https://doi.org/10.1001/ jamainternmed.2013.10059.

37. Kwan JL, Lo L, Sampson M, Shojania KG. Medication reconciliation during transitions of care as a patient safety strategy. Ann Intern Med. 2013;158(5 Pt 2):397-403. doi: https://doi.org/10.7326/0003-4819-158-5-20130305100006.

38. Freitas LFC, Moreira DA, Brito MJM. The continuity of care from the perspective of the being cared for. Cogitare Enferm. 2014[cited 2017 Nov 24];19(4):636-42. Available from: http://revistas.ufpr.br/cogitare/article/view/35993/23930.

\section{Corresponding author:}

Maria Alice Dias da Silva Lima

E-mail: malice@enf.ufrgs.br
Received: 05.07.2018

Approved: 07.12.2018 